\title{
The Evolution of Azerbaijani Identity and the Prospects of Secessionism in Iranian Azerbaijan
}

\author{
Emil Souleimanov *
}

\section{Introduction}

Conventional wisdom has it that Azerbaijanis, the largest ethnic minority in Iran, have historically tended to identify themselves with notions of Iranian statehood and Shiite religion rather than ethnic nationalism, a fact that has made them loyal subjects of Persian states. Yet recent years have shown a considerable growth of their Azerbaijani Turkic self-consciousness as part of their effort to achieve ethno-linguistic emancipation, an emancipation sometimes bordering on separatism and irredentism. Recent developments over the Tabriz-based Tractor Sazi football club (TSFC) and Lake Urmia have provided a further impetus to such developments that offer the potential to endanger the territorial integrity of the Islamic Republic of Iran. This article is an attempt to highlight the evolution of self-consciousness of Iranian Azerbaijanis in recent decades, shedding light on the key issues that have caused this evolution with the aim of exploring the prospects of Azerbaijani secessionism or anti-regime sentiments in the strategically important northwest region of Iran inhabited by ethnic Azerbaijanis.

\section{Iranian Azerbaijanis: An Introduction}

Beginning in the tenth and eleventh centuries, Iran - a term that once had much broader semantic content than it has today-was virtually exclusively ruled by Turkic dynasties and tribes, although these were subsequently subjected to strong Persian cultural influence. ${ }^{1}$ This was not reversed until 1925, when Reza Pahlavi seized power in Tehran and founded the first purely Persian dynasty covering all of Iran in almost a millennium. The careful cultivation of Persian nationalism followed. This was to become the leading ideology in a multiethnic state that had always been distinguished by

Dr. Emil Souleimanov is assistant professor in the Department of Russian and East European Studies at Charles University in Prague, Czech Republic. This article is based on the author's earlier drafts published with the Johns Hopkins University's Central Asia and Caucasus Analyst (CACI Analyst) on 27 October 2010 and 5 October 2011, respectively. This study was carried out in the framework of the Center for the Research of Collective Memory, Faculty of Social Sciences, Charles University in Prague, Czech Republic.

1 For instance, the dynasties of the Ghaznavids, Seljuks, Timurids, Ak Koyunlu, Kara Koyunlu, Safavids, Afsharids, and Qajars were all of Turkic or mixed Turco-Mongol (Timurids) or Turco-Kurdish (Safavid) descent that relied heavily on predominantly Turkic nobility and armies. Until the second half of the nineteenth century, the Turkic language was the language of the military, and for centuries Turkic had been the language of the court. 
a high degree of ethnic and religious tolerance; even today, only roughly half of the country's population is believed to consist of ethnic Persians. ${ }^{2}$

Discrimination against ethnic minorities became a matter of state policy. This involved to no small degree the Turkophone Azerbaijanis, who, as mentioned, with around 20 million members represent the largest ethnic community of this nation of 75 million citizens after the Persians, and have had close cultural and ethno-linguistic ties to Soviet (Caucasian, Northern) Azerbaijan to the north and Turkey to the northwest. In the twentieth century, Persians' concern over the alleged lack of loyalty on the part of Iranian Azerbaijanis toward the idea of Iranian statehood were fostered by the establishment of two short-lived quasi-state entities in Iranian Azerbaijan that declared themselves independent from Tehran, the first in 1920-21 and the second in 1945-46. Intriguingly, during both instances the Iranian northwest was under Communist (Soviet) occupation; following the Soviet withdrawal from this territory, the Soviet-supported national republics in Iranian Azerbaijan ceased to exist, being overwhelmed by Persian (Iranian) armies. Even though popular support among Iranian Azerbaijanis for secession from Iran was far from widespread, reprisals followed in both cases, being particularly harsh in the aftermath of the 1946 instance. $^{3}$

However, in an effort to secure the unity of this multi-ethnic nation, the Pahlavi regime subjected Azerbaijanis to intense assimilatory policies, through which the very ethno-linguistic identity of the Azerbaijani Turks was rejected. Discrimination against their ethno-linguistic rights as well as denial of their distinct identity was commonplace. Azerbaijanis were considered "Turkified Aryans," Iranians by origin, and the authorities promoted a sense of the cultural and racial inferiority of the Turks as descendants of nomadic barbarians, in contrast to the ancient cultivated Persians. It was in the Pahlavi period that the derogatory image of "a stupid Turk" ("Turkish donkey") was cultivated to be applied predominantly to Iranian Azerbaijanis. As a result, millions of Azerbaijanis - especially those that had moved to Teheran and other urban areas of central Iran since the 1960s and 1970s - tended to distance themselves from their Turkishness, assimilating into the Persian socio-linguistic mainstream. Provided they did so, they faced virtually no obstacles in reaching high positions in the state. ${ }^{4}$

The 1979 Islamic Revolution somewhat reduced overt Persian nationalism, giving way to Shiite Islam as the state doctrine of the Islamic Republic. Shiite Islam is common to all of the country's nationalities, save for the great majority of Kurds. Yet the character of Iran as a state made up mainly of Persians remained unshaken.

Tehran's concerns regarding the disposition of its northwestern regions increased with the independence of the Republic of Azerbaijan and the pan-Turkic sentiments

2 James Minahan, Encyclopedia of the Stateless Nations: Ethnic and National Groups Around the World (New York: Greenwood Press, 2002), 1765-66.

3 Touraj Atabaki, Azerbaijan: Ethnicity and the Struggle for Power in Iran (London: I. B. Tauris, 2000), 27-53, 63-99.

4 See, for instance, Alireza Asgharzadeh, "In Search of a Global Soul: Azerbaijan and the Challenge of Multiple Identities," Middle East Review of International Affairs 11:4 (2007): $7-18$. 
voiced by former President Abulfaz Elchibey, who called the "reunification of Azerbaijan a question of five years at the most." Iran even supported Christian Armenia against mainly Shiite Azerbaijan in the war between the two nations in the early 1990s over the disputed Nagorno-Karabakh region. ${ }^{5}$ In the early 1990s, Tehran took preventive measures: it broke up the Iranian province of Azerbaijan into several provinces, and continued to almost exclusively put Persians into office as leaders there. The government has also settled Kurds in areas bordering the Republic of Azerbaijan, seeking to create a sort of cordon sanitaire between the Azeri state and Iran's internal Azerbaijani minority. To further Tehran's strategy, the state has stoked conflict between Kurds and Azerbaijanis. As a result, talk about "Persian fascists" has mostly been heard from among Azeri intellectual emigrants, promoting from exile in Europe and the U.S. the idea of a national revival, freedom, and Turkic unity. Meanwhile, for many ordinary, well-integrated Azerbaijanis who hold leading economic, political, and military posts in modern Iran, the role of a common enemy is played by "Kurdish bandits" rather than by the figure of a Persian oppressor. ${ }^{6}$ Even today, notwithstanding the fundamentals of the Iranian Constitution, which nominally guarantees ethnic minorities' rights to enjoy education in their respective native tongues, education in Azerbaijani Turkish is prohibited, and only a limited number of media outlets print in Azerbaijani, while there is de facto no TV broadcasting in this language. ${ }^{7}$

Yet the situation has changed somewhat since the 1990s, and the establishment of the independent Azerbaijani Republic has played only a partial role in this shift. Over the past decade, Iranian Azerbaijanis have become increasingly vocal in their demands for education in their native tongue and recognition of their Turkic identity. Many thousands of Iranian Azerbaijanis travel frequently to Turkey for both work and recreation, coming to be affected by the strength of Turkish nationalism with its developed sense of pan-Turkic solidarity with both Azerbaijanis and representatives of other Turkic ethnicities. They have also experienced the reality that Turkey is, in comparison to Iran, a much more modern, free, and developed state. Turkish satellite broadcasting, with its rich menu of entertaining programs, has also entered the homes of ordinary Iranian Azerbaijanis, contributing to the improvement of their ethno-linguistic self-perception. Many Azerbaijanis started to regard Turkishness as by no means inferior to Persianness, since Persia, as they also found out, had been ruled predominantly by

5 Emil Souleimanov, "Dealing with Azerbaijan: The Policies of Turkey and Iran toward the Karabakh War (1991-1994)," Middle Eastern Review of International Affairs 15:3 (September 2011); available at http://www.gloria-center.org/2011/10/dealing-with-azerbaijan-thepolicies-of-turkey-and-iran-toward-the-karabakh-war-1991-1994/.

6 Indeed, Iranian Azerbaijanis are known for being well-integrated into Iranian society, as disproportionally high numbers of them are part of the political, economic, military, and cultural elite of Iran. For instance, the supreme leader of the Islamic Republic, Ayatollah Ali Khamenei, and last year's key reformist presidential candidate Mir-Hossein Mousavi are both of Azerbaijani origin.

7 Bijan Baharan, The Hidden Side of Iran: Discrimination Against Ethnic and Religious Minorities (Paris: International Federation for Human Rights, 2010). 
Turkic dynasties for a millennium. Many have come to embrace key personalities of Iranian history of Azerbaijani descent, such as Shah Ismail I, Shah Abbas the Great, Nadir Shah Afshar, and Mohammad Shah Qajar. However, there is general lack of consensus among advocates of emancipation over what should be achieved - whether the goal should be autonomy within Iran, independence, unification with Turkey and/or Azerbaijan, or simply the right to education in Azerbaijani Turkish. Nevertheless, the emancipation movement among Iranian Azerbaijanis has brought about increasing reprisals from state authorities, which culminated during the so-called "cartoon crisis" of May and June 2006 that cost the lives of dozens of Azerbaijani protesters. ${ }^{8}$ To sum up, any manifestations of discontent with the policies of the regime in Tehran brings about harsh reprisals from security forces, as the public space is under the authorities' strict control, which is particularly applied in cases of ethnic unrest or ethno-linguistically flavored demonstrations in the country's peripheries. In Iranian prisons, detainees are routinely subject to torture and humiliation. ${ }^{9}$ Accordingly, the authorities have effectively placed a ban on media coverage of any kind of anti-regime protests.

Nevertheless, the situation of Iranian Azerbaijanis has changed dramatically over recent years, which is facilitated by the overall atmosphere of détente in Iranian society. While two decades ago most Azerbaijanis preferred to speak Persian even in the streets of Azerbaijani-dominated Tabriz, Azerbaijani Turkish has now become commonplace, displacing Persian in most of the predominantly Azerbaijani areas of northwestern Iran. Ordinary Azerbaijanis in Tehran and elsewhere do not hesitate to speak in their native tongue, showing pride in their ethnic identity. Importantly, demonstrations for ethno-linguistic rights have become more frequent in Iranian Azerbaijan. Although they are often violently suppressed by police, with the demonstrators routinely subjected to torture and imprisonment, they still persist. Separatist flags of Southern Azerbaijan are occasionally displayed visibly overnight in Tabriz and other cities of Iran's Azerbaijani northwest, along with posters advocating Azerbaijanis' right to education in their native tongue.

8 In the 14 May 2006 issue of the pro-regime Iran newspaper, two cartoons were published in which the Azerbaijani Turks were likened to an insect. Immediately after the publication of the newspaper, in a manifestation of ethno-politically flavored public discontent that was unprecedented in the history of Iran, hundreds of thousands of ethnic Azerbaijanis took to the streets in the predominantly Azerbaijani-populated cities of Tabriz, Orumiye, Khoy, Zanjan, and even Tehran to protest the publication. Aside from that, demonstrators were calling for the establishment of school education in Azerbaijani Turkish and demanding more ethnocultural rights for their community.

9 For more information on the fate of political prisoners and detainees in Iran, see, for instance, a 2010 Amnesty International study, From Protest to Prison: Iran One Year after the Election; available at www.amnesty.org/en/library/asset/MDE13/062/2010/en/a009a855-788 b-4ed4-8aa9-3e535ea9606a/mde130622010en.pdf. 


\section{Sport Nationalism}

As a result of the imposed restrictions on any politicized expression of Azerbaijani identity, the focus of Azerbaijanis has since then shifted to the realm of sports. The Tabriz-based Tractor Sazi football club has earned massive support of ethnic Azerbaijanis across Iran, breaking all nationwide attendance records. Many thousands of Azerbaijani fans accompany the Tractor football team to its matches, occasionally waving Turkish flags, carrying pan-Turkic symbols and shouting politically-flavored slogans ranging from rather moderate demands to establish school teaching in Azerbaijani Turkic to ones emphasizing their distinctiveness from the Persians ("Hey, look out, I am Turkish"; "Azerbaijan is ours, Afghanistan is yours") to explicitly supporting Azerbaijani separatism ("Long live Azerbaijan and down with those who dislike us"; "Tabriz, Baku, Ankara - our path is different than that of the Persians"). This, in turn, has contributed to growing tensions with the Persian fans, whose racist slurs ("Turkish donkey") are returned by Azerbaijani fans ("Persian dogs" or "Persian monkeys"), which often results in violent clashes, especially during the Tractor's matches with the Teheran-based teams, Persepolis and Esteghlal. ${ }^{10}$ In one instance, on 27 July 2010, following a match marked by mutual rounds of racial insults, the Tractor Sazi football club's Azerbaijani fans engaged in violent clashes with the ethnic Persian fans of the Tehran-based Persepolis football team and Iranian police. During the clashes, dozens of fans were injured, and police jailed dozens of predominantly Azerbaijani fans. ${ }^{11}$

Importantly, this development has taken place alongside increasing numbers of violent incidents pitting Azerbaijanis against Iranian police and security forces being reported across the country. For instance, concerned over the dramatically growing scope of Azerbaijani nationalism aired during TSFC games, the authorities have started to limit the numbers of predominantly Azerbaijani TSFC supporters that are allowed to attend its games. During the frequently occurring racial and nationalistic clashes between Azerbaijani fans of TSFC and the predominantly Persian fans of Esteghlal and Persepolis, police and security forces usually do not hesitate to take the side of the ethnic Persians. A recent victory by TSFC over its traditional rival, Esteghlal, brought about mass celebrations in Tabriz, which were accompanied by political demands. The initiative was crushed by police and security forces and ignited a new wave of detentions of Azerbaijani activists, which continued for several weeks with relation to the Urmia Lake issue, which is detailed below. ${ }^{12}$ In turn, this has been viewed by an increasing share of Iran's Azerbaijani community as additional evidence of ethnic discrimination, anti-Azerbaijani bias, and Persian nationalism.

10 Author's numerous interviews with local Azerbaijanis carried out in Tabriz as part of his fieldwork in the area in September 2010.

11 Azadliq (1 August 2011).

12 Paywand Iran News (15 September 2011); available at http://www.payvand.com/news/11/ sep/1142.html. 


\section{Lake Urmia}

Mass demonstrations by ethnic Azerbaijanis protesting the drying up of Lake Urmia in northwestern Iran - the Middle East's largest water reservoir and the third largest saltwater lake in the world - recently struck the cities of Iranian Azerbaijan. Although information from the region is scarce, numerous reports state that hundreds of protesters have been beaten, arrested, and mistreated by Iranian police and security forces. Additionally, new clashes have taken place between supporters of the Esteghlal and Tractor Sazi football clubs, with the latter raising Urmia-related claims alongside their longtime demands for establishing school education in Azerbaijani Turkish.

Environmental protests have been on the rise since August 2011 following the Iranian parliament's refusal to accept an emergency rescue plan for reviving Lake Urmia, a lake that has the status of a UNESCO biosphere reserve. Indeed, this extremely salty lake (roughly four times as salty as seawater), characterized by unique flora and fauna, could be facing a large-scale environmental catastrophe resembling the fate of Central Asia's Aral Sea. This is a result of Tehran's recent policies of building numerous dams on more than twenty of the tributaries that feed into the lake, which has in turn reduced the average depth of the lake by around two-thirds, to less than 2 meters. The government's plan to build a bridge across the lake connecting the cities of Tabriz and Orumiye has further worsened its ecological situation. ${ }^{13}$

During football matches that took place shortly after parliament's decision, dozens of TSFC fans were arrested for protesting the Iranian government's failure to take measures to save the lake. In spite of the routine detainments of environmental activists and ordinary protesters, several thousand ethnic Azerbaijanis took to the streets of Tabriz, Orumiye, and other cities of Iranian Azerbaijan on 27 August and 3 September 2011, and more demonstrations are expected. These peaceful protests were crushed by large contingents of Iranian police and security forces using repressive means such as tear gas and firing metal bullets. According to local sources, the number of detainees has reached a thousand people, with many dozens of protesters injured and at least one killed.

In the meantime, violence recurred during a football game between TSFC and Esteghlal in Tehran on September 9, in which the TSFC's victory placed it among the leaders of the Iranian playoff. Before the game started, the authorities took measures to prevent thousands of TSFC supporters from entering the stadium. The authorities had received reports about the intention of TSFC supporters to articulate politically-tinged demands during the match, related to the apparent unwillingness of the regime to save Lake Urmia. Those who managed to attend the game still used the opportunity to chant slogans related to Urmia and condemning the authorities, which brought about the clashes with security forces.

Accordingly, long-standing ethno-nationalistic pro-Azerbaijan and pro-Turkey slogans have increasingly come to be accompanied by anti-Persian and anti-regime chants from the bleachers filled with TSFC fans, along with new chants focusing on Lake Ur-

13 Hürriyet Daily News (10 September 2011). 
mia, such as "Lake Urmia is dying, Iran is ordering its execution," or "Urmia is thirsty, Azerbaijan must rise up, otherwise it will lose." Symbolically, these and similar chants were first articulated at a recent meeting of Azerbaijanis at the tomb of Sattar Khan in Tabriz, an ethnic Azerbaijani national hero of Iran and a key figure in the Persian Constitutional Revolution of 1905-11.

Even more importantly, confronted with Tehran's apparent unwillingness to put an effective end to the dehydration of Lake Urmia, increasing numbers of Azerbaijanis regard this as a result of an alleged sophisticated plan by the government to turn Iran's Azerbaijani provinces into a salty desert, as the salt beds left on the desiccated shoreline would be dispersed by winds throughout the whole region, destroying soil and crops. Since Lake Urmia plays a crucial role in Iranian Azerbaijan, and supports up to 15 million local inhabitants, the argument continues, the upcoming ecologic disaster would gradually force local Azerbaijanis to migrate into other areas of the country, effectively reducing the prospects of Azerbaijani secessionism and fostering their assimilation into the Persian mainstream.

\section{Conclusion}

Any signs of nationalism and separatism among Iran's largest ethnic minority, particularly when accompanied by loyalty to external nations, are of outmost concern to authorities in Tehran, as they might endanger the unity of the state, especially in light of Iran's internal problems with its Sunni (Kurdish, Baluchi) and to some extent also Arab minorities and its uneasy relationship with the U.S. and Israel. Although it is too early to envisage catastrophic scenarios for Iran, the ongoing tendency to suppress internal ethnic dissent is not without its potential dangers, and generational factors are leading among them.

In a country where around two-thirds of the population consists of people below the age of thirty, the younger generations of Iranians, especially those inhabiting urban areas, generally tend to have pro-reformist attitudes and wish to live in a freer country, as they showed during last year's protests over the results of presidential elections and subsequent violent reprisals. In fact, the theocratic regime in Iran has alienated many young Iranians, who are now eager to identify themselves not primarily with Shiite Islam but with alternative ideologies. For young Persians, this often takes the form of Persian nationalism, with its emphasis on its pre-Islamic roots, while for many Azerbaijanis, it is increasingly Azerbaijani nationalism, with its pan-Turkic overtones.

The ongoing split in Iranian society along social and ethnic lines is paralleled by the split within the Azerbaijani community itself. In this split, rural, less educated, deeply religious, and usually older Azerbaijanis, who are supportive of the conservatives, still link Shiite religion (the main layer of their self-identification) with Iran, and stick to the centuries-old tradition of referring to the Sunni Turks as heretics. For them, those who in their opinion seek the dismemberment of their Iranian homeland are traitors and "agents of Israel." However, as ethnic polarization within Iran deepens, they too are affected negatively by the increasingly anti-Turkic sentiments of their Persian compatriots, and are thus becoming increasingly aware of their ethnic roots. On the 
other hand, pro-reformist, relatively educated Azerbaijani youth from urban areas generally incline toward ethnic nationalism, increasingly dissociating themselves from the Persians and adopting a stance that is oriented more towards Turkey and Azerbaijan. Whether or not the current emancipation stage of Azerbaijani nationalism results in separatist efforts over time now depends on the ability of Tehran to further secure the favor of its loyal Azerbaijani population while simultaneously keeping Azerbaijani nationalists and their rhetoric off the public stage, possibly meeting their basic ethno-linguistic and cultural demands. In any case, the genie of Azerbaijani nationalism is already out of the bottle.

So far, the significant successes and wide popularity across northwestern Iran's predominantly Azerbaijani provinces of the Tractor Sazi football club has contributed greatly to awakening the masses of once politically apathetic Iranian Azerbaijanis. The commitment to save Lake Urmia, regarded as the pearl of Iranian Azerbaijan, has further united many ordinary Azerbaijanis. This is regardless of their political feelings toward the idea of Iranian statehood or Azerbaijani Turkic nationalism, as well as efforts aimed at ethno-linguistic and cultural emancipation advocated by a portion of the Iranian Azerbaijani population. The indiscriminate use of force by the regime, even over this seemingly apolitical issue, has further deepened the ethnically-defined gap between Iranian Azerbaijanis and the Iranian state, paving the ground for considerable conflict in the future. 
WINTER 2011

\section{Bibliography}

Atabaki, Touraj. Azerbaijan: Ethnicity and the Struggle for Power in Iran . London: I. B. Tauris, 2000.

Baharan, Bijan. The Hidden Side of Iran: Discrimination Against Ethnic and Religious Minorities In Paris: International Federation for Human Rights., 2010.

In Search of a Global Soul: Azerbaijan and the Challenge of Multiple Identities. Middle East Review of International Affairs 11, no. 4 (2007): 7-18.

Minahan, James. Encyclopedia of the Stateless Nations: Ethnic and National Groups Around the World. New York: Greenwood Press, 2002.

Souleimanov, Emil. "Dealing with Azerbaijan: The Policies of Turkey and Iran toward the Karabakh War (1991-1994)." Middle Eastern Review of International Affairs 15, no. 3 (2011). 